\title{
Investigation of Effective Microorganisms Application Method on Alleviation of Salt Stress Effects on Root Morphology of Sweet Corn
}

\author{
Zahra Sabeti' $\cdot$ Mohammad Armin ${ }^{1 *} \cdot$ Mohamad Reza Vaezi Kakhki \\ ${ }^{1}$ Department of Agronomy and Plant Breeding, Sabzevar Branch, Islamic Azad University, Sabzevar, Iran \\ ${ }^{2}$ Department of Biology, Hakim Sabzevari University, Sabzevar, Iran
}

\begin{abstract}
Summary: Root morphology can be affected by many factors such as microorganisms. To determine the effect of effective microorganisms (EM) on the root morphology of sweet corn under salt stress, a factorial experiment was carried out in a randomized complete block design with three replications in Islamic Azad University of Sabzevar in 2013. Examined factors included application method of EM (soil application, foliar application and soil+foliar application) and intensity of salinity $(0,25,50,75 \mathrm{mM})$. Commercial solution of EM was applied at 30 liters per hectare for soil application and foliar application during five-leaf stage. The highest root dry weight, root density and membrane stability were observed in soil application while the highest root volume, root length, root and shoot dry weight occurred when soil and foliar application were performed together. With increasing intensity of salinity, all traits decreased and the highest traits were observed in the control treatment. Soil application of EM in comparison with other methods alleviates effects of salinity under saline conditions.

Keywords: effective microorganisms (EM), root morphology, sweet corn, salinity
\end{abstract}

\section{Introduction}

Sweet corn (Zea mays L. var. Saccharata) is corn with a mutation on the locus Su (Sugary) on chromosome number 4 . The genetic variation causes the accumulation of soluble sugars and polysaccharides in the endosperm of seeds (Tracy and Hallauer, 1994). Unlike corn, which is one of the cereals used to feed livestock or the production of flour, sweet corn is used as a vegetable and fresh food for humans. Nowadays, sweet corn is one of the most popular vegetables in different parts of the world and its consumption is increasing due to its delectability and richness in vitamins. Sweet corn is often planted for its inflorescences. The crop value of this crop for processing (canning and freezing) and as a fresh vegetable is the second and fourth respectively (Afsharmanesh, 2013). In 2003, the area under sweet corn cultivation in the world was 1,019,698 hectares with an average production of $8,602 \mathrm{~kg}$ per hectare which $8,772,112$ tons of corn were produced. About 27 percent of corn acreage and 46 percent of the world belongs to the United States and the largest producers of corn are America, Nigeria, France, Hungary, Peru, South Africa and Japan, respectively (Hampton, et al., 2017).

Corresponding author: armin@iaus.ac.ir
Drought and salinity are the most common environmental stresses throughout the world, including Iran (Golbashy et al., 2010). There is a lack of research on the effects of salinity on sweet corn; however, it is believed that sweet corn is semi-sensitive to salinity and the most sensitive crop among the cereals (Maas and Hoffman, 1977). Research on sweet corn hybrids response to salt stress showed that although hybrids have identical response to salt stress, seed germination, root length, stem length, fresh and dry weight of roots and stems are reduced with increasing of salinity. Also, salinity increases the amount of malondialdehyde, proline and $\mathrm{H}_{2} \mathrm{O}_{2}$ in the seedling (Shtereva et al., 2015). It has been reported that grain yield, grain weight, fertility and plant within florescent decreased with increasing salinity from 2 to $8 \mathrm{dS} / \mathrm{m}$ (Shahrokhi and Khorasani, 2013). Turan et al. (2009) reported that increasing intensity of salinity from 0 to $100 \mathrm{mM}$ increased concentration of sodium, chlorine, phosphorus, zinc and manganese in roots and shoots, but decreased concentration of iron, calcium and sodium in the shoot. Hussain et al. (2015) examined the effects of salinity on growth and sharing of mineral nitrogen in corn and reported that dry weight of leaf, stem and root were significantly reduced by salinity. Pessarakli et al. (1989) studied the effect of salinity on dry weight, water absorption and the amount of nitrogen in corn leaves under salinity stress and reported 
that all level of salinity, significantly reduced root development and biomass and this reduction increased with increasing salinity. The dry weight of plants in the osmotic pressure of 3, 6, and 9 bar was 78, 19.4, and $6.4 \%$ of dry weight control, respectively. Also water and nutrients absorption decreased in stress conditions.

One of the ways to achieve sustainable agriculture is the use of microorganisms that play an important role in providing protection and nutrient needs of the plants. Currently, the use of growth promoting bacteria capable of symbiosis with the roots of many legume crops have become common and their role in processes of biological nitrogen fixation in plants has proved this method of cooperation (Nazarly and Seyed, 2013). Effective microorganisms, that are today one of the biological fertilizers, have been of interest to many researchers. Effective microorganisms (EM) are a combination of free and beneficial microscopic organisms found in nature and include various blends of common predominantly anaerobic microorganisms. The detailed composition is kept secret. The main species included in EM preparations are lactic acid bacteria Lactobacillus plantarum, Lactobacillus casei, Streptococcus lactis, photosynthetic bacteria Rhodopseudomonaspalustris and Rhodobactersphaeroides, the yeasts Saccharomyces cerevisiae and Candida utilis, the Actinomycetes Streptomyces albus and Streptomyces griseus, and finally the fungi Aspergillus oryzae and Mucorbiemalis that develop safety and yield of products through increase photosynthesis and production of bioactive compounds such as the hormones and the enzymes, accelerating the decomposition of lignin materials in the soil and controlling soil-borne diseases (Higa, 2000). The population of beneficial microorganisms in the soil increases plant resistance to root diseases and environmental stress such as heavy metal toxicity and lack of water and nutrition (Singh et al., 2011).The use of EM with organic fertilizer is a good way to secure and release of nutrients from fertilizer sources. Many studies showed that soil inoculation with EM, in addition to increasing the quality and quantity of crop production, increases soil quality (Higa, 2001). Javaid (2006) reported that the use of EM in the enrichment of cattle manure in wheat, increased wheat yield by $27 \%$ compared to the consumption of alone chemical fertilizer. Maximum dry weight obtained when the cattle manure was associated with a 3\% EM. Corn has also been reported that enrichment of poultry manure with EM increases the absorption rate of nutrients and ultimately increase the seed yield (Priyadi et al., 2005). The pepper spray with fertilizer EM is a safe alternative to chemical fertilizers to increase yield (Javaid, 2006). Studies Jahanban and Lotfifar (2012) on the impact of EM on the performance of two corn varieties showed that EM increases the yield and yield components in two cultivars, so that the increase in single cross variety of 704 had more than 666 backcrosses. Lee and Sung (2001) in their study indicated that the use of EM compost to produce organic tomato can increase soil
$\mathrm{pH}$ and absorption of phosphorus, potassium and improve the micronutrient status and soil organic matter.

Most studies focus on salt stress impact on the shoot growth of plant, however, the reaction of root exposure to environmental factors such as salinity is less considered. Majdi et al. (2013) reported significant difference between corn inbred lines to salinity stress which MO17 inbred line was more sensitive to salinity compared to B73. Salinity stress significantly decreased total root volume, root area, root length, root dry weight, shoot dry weight and root/shoot ratio, but increased root diameter and specific root weight. Borzouei et al. (2015) reported that the decrease in root dry weight, shoot dry weight, root to shoot ratio and root varieties due to increased volume and surface salinity occurs in 6 to $8 \mathrm{dS} / \mathrm{m}$. Changes in yield were largely due to changes in root dry weight per plant and varieties with more root dry weight had better performance. Between root volume and root dry weight was closely related with grain yield. Increased root surface area, by increasing absorption of water and nutrients is important in increasing efficiency; therefore, longer roots and more root surface can provide the possibility of higher tolerance. The plant roots can indicate the contact area with the soil and the possibility to provide more access to water.

Due to sweet corn as a plant growth period short which can play an important role in human nutrition and the fundamental importance of root as the first organ exposed to environmental stresses in rhizosphere happen and also lack of proper ecological methods to reduce stress on the plants, this study was conducted to determine the root morphological and physiological response to salt stress on sweet corn.

\section{Materials and Methods}

The survey was conducted in the research greenhouse of Islamic Azad University in 2015 in a factorial randomized complete block design with three replications. The experimental factors included; EM application method in three levels (soil application, foliar application and soil +foliar application) and salinity $(0,25,50,75 \mathrm{mM})$. The EM commercial solution was used at 30 liters per hectare for soil application and foliar application in the five-leaf stage.

Sweet corn was planted in pots with a diameter of $25 \mathrm{~cm}$ at a depth of $5 \mathrm{~cm}$. After ensuring complete and optimal development of plants, 5 plants per pot were maintained, and the rest of the plants were excluded. The soil used was a mixture of clay and sand. $75 \mathrm{~kg} \cdot \mathrm{ha}^{-1}$ $\mathrm{P}_{2} \mathrm{O}_{5}$ and 50 kg.ha- ${ }^{-1} \mathrm{~K}_{2} \mathrm{O}$ (as Super phosphate and potassium sulfate source, respectively) as a base before applying the treatments were mixed with soil and pots. $100 \mathrm{~kg} \cdot \mathrm{ha}^{-1} \mathrm{~N}$ as urea form as a nitrogen source was used in two stages of plant growth, in the three-leaf and eight-leaf stage. Other plant needs, based on observation 
of symptoms on the plant was carried out. Each pot was watered by adding different amounts of sodium chloride in water, depending on the type of treatment, after the establishment of the plants watering interval was 10 days.

At flowering stage, to measure the relative water content (RWC), 2 apical leaves of each plant were separated, then prepared using the disc-shaped punching machine and parts immediately weighed (W1). The disk was placed for 24 hours in the dark and distilled water, weighed again (W2), exposed for 48 hours at $70^{\circ} \mathrm{C}$ and then weighed (W3).

\section{$\mathrm{RWC}=\mathrm{W} 1-\mathrm{W} 3 / \mathrm{W} 2-\mathrm{W} 3$}

Measurement of membrane stability index (MSI) was performed using $200 \mathrm{mg}$ of leaf tissue immersed in two different flasks containing $10 \mathrm{cc}$ of distilled water. One of the flasks was placed for 30 minutes at $40{ }^{\circ} \mathrm{C}$ water bath and immediately electrical conductivity of the solution was determined using a conductivity meter (C1). The second flask was placed at $100^{\circ} \mathrm{C}$ for 10 minutes and then measured the electrical conductivity of the solution (C2).

$$
\mathrm{MSI}=[1-(\mathrm{C} 1 / \mathrm{C} 2)]^{* 100}
$$

When corn plants reached the reproductive growth stage, shoot and root growth characteristics were evaluated in order to evaluate these attributes, the corn plants were removed entirely from the pots, and divided into two parts of root and shoot. All soils were washed to remove roots. Then the roots were transferred to the laboratory for morphological characterization. In the laboratory, the roots were stained with exposure to methyl violet, and then the roots were scanned by root analysis system (Delta-T SCAN Image Analysis System, Delta-T Devices Ltd, U.K.) for measuring features such as root volume, total root, root diameter and total root length. After examining the morphological characteristics of root, root and shoot samples were transferred to an oven at $75{ }^{\circ} \mathrm{C}$ for 48 hours. The root and shoot dry weight was measured using a digital scale. Root to shoot ratio was calculated by dividing the plant root dry weight $(\mathrm{mg})$ to root length $(\mathrm{cm})$ and weight for the roots $(\mathrm{mg} / \mathrm{cm})$. The data were analyzed using SAS software and the averages were compared by Duncan test. Tables and figures were drawn in Excel software.

\section{Results and Discussion}

Analysis of variance showed that EM application method had a significant effect on root diameter, root volume, root length and root surface area. EM application had no effect on relative water content, membrane stability index and density of roots. Salinity and the interaction of salinity and EM application had a significant effect on root diameter, root volume, root length, root area, relative water content, membrane stability index and specific gravity (Table 1).

Membrane Stability Index (MSI)

Soil application of effective microorganisms was more effective than spraying on the membrane stability index, although no significant difference was observed between soil application in addition to foliar, and soil application alone (Table 2). It seems that, microorganisms present in the biological materials are easily absorbed through roots and enter the cell organs, which increases the stability of the membrane in response to environmental conditions.

There was no statistical difference between the salt concentration of $25 \mathrm{mM}$ and control, in terms of membrane stability index, although membrane stability index was highest in control treatment and membrane

Table 1. Analysis of variance table for MSI, RWC, shoot and root length, shoot and root dry weight, root volume, root surface area, specific root weight

\begin{tabular}{|c|c|c|c|c|c|c|c|c|c|c|}
\hline SOV & df & MSI & RWC & $\begin{array}{l}\text { Shoot } \\
\text { Length }\end{array}$ & $\begin{array}{l}\text { Root } \\
\text { Length }\end{array}$ & $\begin{array}{c}\text { Root } \\
\text { Dry } \\
\text { Weight }\end{array}$ & $\begin{array}{c}\text { Shoot } \\
\text { Dry } \\
\text { Weight }\end{array}$ & $\begin{array}{c}\text { Root } \\
\text { Volume }\end{array}$ & $\begin{array}{c}\text { Root } \\
\text { Surface } \\
\text { Area }\end{array}$ & $\begin{array}{c}\text { Specific } \\
\text { Root } \\
\text { weight }\end{array}$ \\
\hline Replication & 2 & $10.12^{\mathrm{ns}}$ & $28.5^{\mathrm{ns}}$ & $4.96^{\mathrm{ns}}$ & $16681^{\text {ns }}$ & $0.04^{\mathrm{ns}}$ & $9.14^{\mathrm{ns}}$ & $1.51^{\mathrm{ns}}$ & $1681^{*}$ & $0.00001^{\mathrm{ns}}$ \\
\hline $\begin{array}{l}\text { Application } \\
\text { method }\end{array}$ & 2 & $69.68^{\mathrm{ns}}$ & $298^{\mathrm{ns}}$ & $640^{* *}$ & $48870^{* *}$ & $0.19 \mathrm{~ns}$ & $5.21 \mathrm{~ns}$ & $7280^{\text {ns }}$ & $48870^{* *}$ & $0.00012^{\text {ns }}$ \\
\hline Salinity & 3 & $257^{* *}$ & $485^{*}$ & $1506^{* *}$ & $88534^{* *}$ & $1.30^{* *}$ & $124^{* *}$ & $7407^{* *}$ & $88534^{* *}$ & $0.00016^{\mathrm{ns}}$ \\
\hline Interaction & 6 & $77.6^{*}$ & $8.1^{\mathrm{ns}}$ & $212^{*}$ & $10079^{* *}$ & $0.42^{* *}$ & $1.31^{\mathrm{ns}}$ & $871^{\text {ns }}$ & $10079^{* *}$ & $0.0011^{* *}$ \\
\hline Error & 22 & 23.8 & 101 & 15.89 & 706.9 & 0.06 & 2.04 & 5089 & 706 & 0.00005 \\
\hline $\mathrm{CV}$ & & 5.76 & 21.83 & 9.77 & 10.48 & 28.94 & 24.60 & 11.47 & 10.48 & 32.44 \\
\hline
\end{tabular}

ns: not significant; $(*)$ and $(* *)$ represent significant difference over control at $\mathrm{P}<0.05$ and $\mathrm{P}<0.01$, respectively. 
Table 2. Membrane stability index and relative water content in sweet corn under different levels of salinity and EM application method

\begin{tabular}{|c|c|c|c|c|c|c|c|c|}
\hline \multirow{2}{*}{$\begin{array}{l}\text { Salinity } \\
(\mathrm{mM})\end{array}$} & \multicolumn{3}{|c|}{ EM Application method } & \multirow[t]{2}{*}{ Mean } & \multicolumn{3}{|c|}{ EM Application method } & \multirow{2}{*}{ Mean } \\
\hline & Soil & Foliar & Soil + Foliar & & Soil & Foliar & Soil + Foliar & \\
\hline & \multicolumn{4}{|c|}{ Relative Water Content ( $\%)$} & \multicolumn{4}{|c|}{ Membrane Stability Index (\%) } \\
\hline 0 (Control) & 58.06 & 51.60 & 54.2 & 54.62 & 88.75 & 92.65 & 88.74 & 90.04 \\
\hline 25 & 54.78 & 42.54 & 45.82 & 47.72 & 88.52 & 87.84 & 84.15 & 8484 \\
\hline 50 & 52.44 & 39.86 & 44.45 & 45.58 & 87.42 & 83.14 & 82.12 & 84.23 \\
\hline 75 & 41.37 & 33.65 & 35.38 & 36.80 & 8471 & 67.29 & 80.39 & 77.46 \\
\hline Mean & 51.66 & 41.95 & 44.97 & & 87.35 & 82.73 & 83.85 & \\
\hline \multirow[t]{2}{*}{$\mathrm{LSD}_{0.05}$} & $\begin{array}{l}\text { Application } \\
\text { method }\end{array}$ & Salinity & $\begin{array}{r}\text { Application } \mathrm{m} \\
\text { Salinit }\end{array}$ & & $\begin{array}{l}\text { Application } \\
\text { method }\end{array}$ & Salinity & $\begin{array}{r}\text { Application me } \\
\text { Salinity }\end{array}$ & \\
\hline & 8.53 & 9.85 & 17.07 & & 4.13 & 4.77 & 8.26 & \\
\hline
\end{tabular}

stability index was the lowest in $75 \mathrm{mM}$ salt treatment (Table 2). It is reported that membrane stability index in response to salt reduction is related to the effect of salt on the electric potential of the plasma membrane (Azarmi et al., 2016).

\section{Relative Water Content}

The application method of EM and interaction of salinity and application method did not have significant effect on relative water content while salinity at 0.01 significance level was affected by it (Table 1). The highest relative water content was observed in nonsalinity treatment and the lowest was found at $75 \mathrm{mM}$ (Table 2). There was a linear relation between relative water content and soil salinity.

\section{Shoot and Root Length}

As shown in Table 3 soil+foliar application of EM had the highest shoot length. There was no significant difference between soil+foliar application and soil application of EM, while foliar application of EM had the lowest shoot length (Table 3).It seems that in more growth of root and more water absorbed by root due to soil application of EM caused more increasing of shoot length. It has been suggested that EM had no hormonal properties. It was reported that plant height increase due to application of biological fertilizer was related to more absorbing of nutrient especially nitrogen and phosphorus and improvement of photosynthesis can resulted in more plant height (Yamada and $\mathrm{Xu}, 2001$ ).

Shoot length significantly decreased with increasing of soil salinity. Shoot length was reduced by $150 \%$ at 75 $\mathrm{mM}$ compared than non-salt stress treatment (Table 3). The adverse effect of high salinity in plant height was previously shown (Taffouo et al., 2009).

Higher alleviation effect was observed in soil and soil+foliar application of EM. At high salinity level shoot length dramatically was decreased in all application method. Up to $50 \mathrm{mM}$ soil application of EM decreased salinity effect on shoot length and there was not significantly difference between 25 and $50 \mathrm{mM}$ where as in foliar application low salinity stress $(25 \mathrm{mM})$ was reduced by $15 \%$ than control (Table 3 ).

Results of the mean comparisons indicated that soil+foliar application of EM achieved the highest root length, and foliar application, caused the lowest root length. So that EM's soil+foliar application increased to $0.92 \%$ root length compared to foliar application (Table 3). In general, because of supplying a large amount of food energy by the active root system, the roots of the plants collect a large population of microorganisms in their surrounding area which can be up to $50 \%$ surroundings. Compounds such as amino acids, soluble amides, sugars and low molecular weight compounds are awarded microorganisms by the roots. When bacteria gather around plant roots, secrete substances that cause impact on the growth and root morphology (Kazemeini et al., 2010). The foliar application of EM is not only an additive effect on root length, but because of the influence of nutrition on biomass plants may reduce root growth.

In the absence of salinity was the highest root length, and with increasing salinity levels was observed a significant decrease in root length. No significant differences were observed in root length in salinity of 25 and $50 \mathrm{mM}$ (Table 1). Reduced root growth was due to osmotic effects or ions through the root zone. Reduction of root length with increasing salinity has also been reported in corn (Majdi et al., 2013) and wheat (Borzouei et al., 2015).

Interaction of application method of EM and salinity on the root length showed that foliar application of effective microorganisms could not reduce the negative effects of salinity and the negative effects of salinity were higher in the treatment compared to other methods of applying. Using soil+foliar application was the most appropriate treatments, in terms of reducing the negative effects of salinity on total root length so that in this treatment, total root length was reduced to conditions of salinity to $50 \mathrm{mM}$ salinity level, but this reduction was lower compared to other treatments (Table 3). It is reported that plant nutrition can reduce 
Table 3. Shoot and root length in sweet corn under different levels of salinity and EM application method

\begin{tabular}{|c|c|c|c|c|c|c|c|c|}
\hline \multirow{2}{*}{$\begin{array}{l}\text { Salinity } \\
(\mathrm{mM})\end{array}$} & \multicolumn{3}{|c|}{ EM Application method } & \multirow[t]{2}{*}{ Mean } & \multicolumn{3}{|c|}{ EM Application method } & \multirow{2}{*}{ Mean } \\
\hline & Soil & Foliar & Soil + Foliar & & Soil & Foliar & Soil + Foliar & \\
\hline & \multicolumn{4}{|c|}{ Shoot Length $(\mathrm{cm})$} & \multicolumn{4}{|c|}{ Root Length $(\mathrm{cm})$} \\
\hline 0 (Control) & 65.01 & 50.33 & 54.23 & 57.83 & 42.66 & 27.42 & 47.17 & 39.09 \\
\hline 25 & 57.76 & 29.23 & 45.82 & 41.61 & 36.02 & 16.56 & 43.70 & 32.094 \\
\hline 50 & 50.76 & 31.48 & 44.45 & 36.99 & 29.64 & 17.62 & 40.19 & 29.15 \\
\hline 75 & 22.86 & 30.29 & 35.38 & 26.77 & 14.3 & 15.47 & 16.91 & 15.56 \\
\hline Mean & 49.09 & 35.33 & 37.98 & & 30.66 & 19.26 & 36.99 & \\
\hline \multirow[t]{2}{*}{$\operatorname{LSD}_{0.05}$} & $\begin{array}{l}\text { Application } \\
\text { Method }\end{array}$ & Salinity & \multicolumn{2}{|c|}{$\begin{array}{l}\text { Application method } \times \\
\text { Salinity }\end{array}$} & $\begin{array}{l}\text { Application } \\
\text { method }\end{array}$ & Salinity & \multicolumn{2}{|c|}{$\begin{array}{l}\text { Application method } \times \\
\text { Salinity }\end{array}$} \\
\hline & 3.37 & 3.89 & 6.75 & & 3.41 & 3.93 & 6.81 & \\
\hline
\end{tabular}

the effects of salinity which the situation on the one hand has been achieved using foliar application of effective microorganisms, on the other hand, increase access to water and mineral nutrients through soil application, also provides improved root growth which increases the total root length. In general, osmotic stress begins with increasing the salt concentration in the root, then shoot growth rate is also reduced dramatically by crossing the threshold of tolerance, and ultimately it leads to a reduction in root due to reduction of plant photosynthetic rate (Amiri et al., 2015).

\section{Root and Shoot Dry Weight}

The statistical comparison of results showed that the addition of EM into the soil, root dry weight increased to $46.1 \%$ compared with foliar application of EM (Table 4). Increased root dry weight gains due to the positive impact of applying EM into soil can be attributed to microorganisms present in the manure through the root zone. It is reported that plant physiological responses to the use of effective microorganisms depends on the number of years used and the type of plant. Javaid (2006) reported that the use of effective microorganisms for soil and foliar application, however, shoot dry weight increased, but reduced root dry weight, because it would reduce competition between microorganisms present in the manure and microorganisms in the soil were compared, which compete for food availability and access to food for the plant would decrease resulting in reduced root growth occurs. In this study, the use of effective microorganisms are sprayed on dry root weight had more beneficial effects than other methods.

In the control root dry weight was the highest, and the lowest values were obtained in the treatment of 75 $\mathrm{mM}$ salinity (Table 4). Increased salinity in the root zone, resulting in a greater photosynthetic material to other metabolic pathways involved in stress tolerance. It has been reported that leaf expansion stops at the start of salinity and drought, while carbon capture still remains at close to normal values. Additional carbon products may be stored and used for osmotic adjustment or allocated to growth (Cirillo et al., 2016).

The interaction of applying method and salt stress on root dry weight showed that soil application of effective microorganisms in soil and salinity of $25 \mathrm{mM}$ increased root dry weight compared with the control, while in other methods, the use of effective microorganisms, increasing salinity decreased root dry weight compared with the control which the amount of reduction in application of EM compared to other methods were sprayed using EM (Table 4).

Table 4. Root and shoot dry weight in sweet corn under different levels of salinity and EM application method

\begin{tabular}{|c|c|c|c|c|c|c|c|c|}
\hline \multirow{2}{*}{$\begin{array}{l}\text { Salinity } \\
(\mathrm{mM})\end{array}$} & \multicolumn{3}{|c|}{ EM Application method } & \multirow[t]{2}{*}{ Mean } & \multicolumn{3}{|c|}{ EM Application method } & \multirow{2}{*}{ Mean } \\
\hline & Soil & Foliar & Soil + Foliar & & Soil & Foliar & Soil + Foliar & \\
\hline & \multicolumn{4}{|c|}{ Root Dry Weight (g per plant) } & \multicolumn{4}{|c|}{ Shoot Dry Weight (g per plant) } \\
\hline 0 (Control) & 1.61 & 1.21 & 0.93 & 1.25 & 8.67 & 9.56 & 10.92 & 9.72 \\
\hline 25 & 0.84 & 0.53 & 0.49 & 0.62 & 6.87 & 8.50 & 9.34 & 8.24 \\
\hline 50 & 0.41 & 0.25 & 0.68 & 0.44 & 2.60 & 3.05 & 3.39 & 3.02 \\
\hline 75 & 0.25 & 0.13 & 0.21 & 0.18 & 2.36 & 2.32 & 2.10 & 2.26 \\
\hline Mean & 0.768 & 0.53 & 0.582 & & 5.12 & 5.86 & 6.44 & \\
\hline \multirow[t]{2}{*}{$\mathrm{LSD}_{0.05}$} & $\begin{array}{l}\text { Application } \\
\text { method }\end{array}$ & Salinity & $\begin{array}{r}\text { Application m } \\
\text { Salinit }\end{array}$ & & $\begin{array}{l}\text { Application } \\
\text { method }\end{array}$ & Salinity & $\begin{array}{r}\text { Application me } \\
\text { Salinity }\end{array}$ & \\
\hline & 0.21 & 0.23 & 0.41 & & 1.21 & 1.39 & 2.42 & \\
\hline
\end{tabular}


Salinity due to sodium chloride had significant effect on shoot dry weight of sweet corn. According to the results of mean comparison, the highest shoot dry weight in soil+foliar treatment, and the lowest shoot dry weight was observed in treatments using EM into soil. Soil treatment associated with foliar caused an increase of $20 \%$ of shoot dry weight compared to method of soil treatments alone (Table 4). Merah and Monneveux (2015) in a survey which was based on the dry weight of the plant, showed that the participation of stem material increased grain yield in stress conditions. It seems that the use of biofertilizers increased the number of leaves and chlorophyll content. Leaf has an important role as the major organs of plants to perform photosynthesis and produce assimilates in plants. With the increasing number and leaf area, the plant can produce enough food in the presence of light, therefore increases the amount of photosynthesis that this phenomenon increases photosynthesis and ultimately increase the shoot dry weight. Soil application of effective microorganisms was the highest efficiency in root to shoot ratio (root dry weight to shoot dry weight). Foliar application of effective microorganisms could no produce a good root to shoot ratio. Changes in this ratio indicate that the growth of root and shoot growth will be affected at the same time, and almost equal to the use of effective microorganisms.

\section{Root Volume}

There was a significant difference between treatments in terms of soil application with the rest treatment in case of root volume. So that soil+foliar application at the same time, led to the production of the highest volume at the roots in sweet corn but the lowest volume by foliar application. In such a way that the use of soil application, showed an increase of $121 \%$ compared to foliar (Table 5). It was reported that shoot dry weight of the pistachio seedling treated with the plant growth promoting rhizobacteria (PGPR) significantly increased comparison with the control. Production of organic acids, enzyme ACC-deaminase, IAA, siderophore, $\mathrm{HCN}$ as well as increasing the bioavailability of nutrients such as $\mathrm{P}, \mathrm{Zn}$ and $\mathrm{K}$ are reasons for the improvement of the pistachio seedling growth inoculated with fluorescent pseudomonads rhizobacteria (Azarmi et al., 2016).

Control sweet corns had the highest root volume, but treatment with $75 \mathrm{mM}$ had the lowest. Increased salinity reduced $34.71 \%$ of the plant root (Table 5). Significant decrease in inbred corn root volume is reported in salinity of 50 and $100 \mathrm{mM}$ compared with non-stress condition in the study of (Majdi et al., 2013).Similar results have been reported about the negative effects of salt stress on the root volume reduction(Robin et al., 2016a). Borzouei et al. (2015) reported that more of the root volume in salinity was due to higher salt tolerance of plants tolerant to salinity. Kazemi et al. (2016) reported the gradual change in root volume was sigmoid in levels of salinity 0,20 and 30 $\mathrm{dS} / \mathrm{m}$, but speed and its value decreased with increasing salinity. However, the root volume increased by sigmoid with a lower slope in the salinity level of $10 \mathrm{dS} / \mathrm{m}$.

The interaction of application method and salinity levels on the root volume showed that in soil+foliar application, the lowest change was observed in the volume root, and root volume decline was observed in foliar application. The beneficial effects of some symbiotic aerobic and anaerobic organisms in EM in soil application could have been the important factor to more tolerant and less changes in the treatment (Table 5). It is reported that the use of effective microorganisms improves soil conditions and enhance the absorption of nutrients, such as phosphorus and nitrogen by plant and these two elements increase shoot growth and root growth respectively. Wang et al. (2016) suggest that photosynthetic bacteria in the effective microorganisms increase the amount of photosynthesis in plants that it can provide more materials for the development of other organs such as roots.

\section{Root Surface Area}

With regard to the comparison of means, the highest root surface area was observed in sweet corn roots in soil combined to foliar application and the lowest one was seen in treatment of foliar application. Application of soil combined to foliar treatment increased root surface area 67\% compared to foliar (Table 5). The

Table 5. Root volume and root surface area in sweet corn under different levels of salinity and EM application method

\begin{tabular}{|c|c|c|c|c|c|c|c|c|}
\hline \multirow{2}{*}{$\begin{array}{l}\text { Salinity } \\
(\mathrm{mM})\end{array}$} & \multicolumn{3}{|c|}{ EM Application method } & \multirow[t]{2}{*}{ Mean } & \multicolumn{3}{|c|}{ EM Application method } & \multirow{2}{*}{ Mean } \\
\hline & Soil & Foliar & Soil + Foliar & & Soil & Foliar & Soil + Foliar & \\
\hline & \multicolumn{4}{|c|}{ The Root Volume $\left(\mathrm{m}^{3}\right)$} & \multicolumn{4}{|c|}{ Roots Surface Area $(\mathrm{cm})$} \\
\hline 0 (Control) & 91.16 & 80.76 & 115.47 & 95.80 & 405.84 & 226.44 & 403.58 & 345.29 \\
\hline 25 & 74.35 & 34.21 & 104.18 & 70.91 & 290.86 & 257.66 & 394.22 & 314.25 \\
\hline 50 & 37.43 & 24.79 & 101.78 & 54.68 & 217.86 & 137.01 & 341.87 & 232.25 \\
\hline 75 & 28.39 & 20.45 & 33.51 & 27.45 & 116.37 & 13.19 & 122.43 & 123.33 \\
\hline Mean & 57.83 & 40.05 & 88.73 & & 257.74 & 188.08 & 315.52 & \\
\hline \multirow[t]{2}{*}{$\mathrm{LSD}_{0.05}$} & $\begin{array}{l}\text { Application } \\
\text { method }\end{array}$ & Salinity & \multicolumn{2}{|c|}{$\begin{array}{l}\text { Application method } \times \\
\text { Salinity }\end{array}$} & $\begin{array}{l}\text { Application } \\
\text { method }\end{array}$ & Salinity & \multicolumn{2}{|c|}{$\begin{array}{l}\text { Application method } \\
\times \text { Salinity }\end{array}$} \\
\hline & 6.04 & 6.67 & 12.08 & & 22.51 & 25.99 & 15.02 & \\
\hline
\end{tabular}




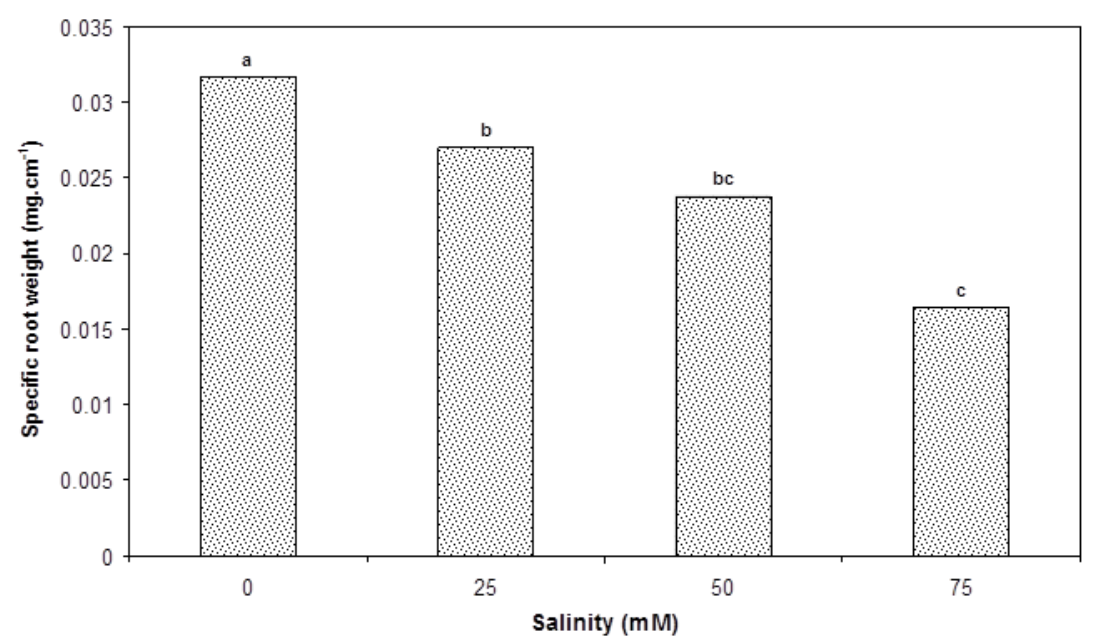

Figure 1. Influence of salinity level on specific root weight

use of soil microorganisms, particularly bacteria that are stimulating growth, with different reproductive processes involved in plant growth and nutrient cycle, increases root surface area in wheat (Hodge and Storer, 2015).

Sweet corn root surface area decreases with increasing salinity levels. So that the root surface area was the highest level in control and was the lowest level in the salinity of 75 $\mathrm{mM}$ (Table 5). Reduced root surface area with increasing salinity levels can be caused by a decrease in the number of lateral root and original products under osmotic stress and drought. Majdi et al. (2013) also reported a decrease in root surface area by increasing salinity in corn inbred lines. Increasing salinity also affects the level of root mass and reduces root after decreasing the other characteristics such as weight and root depth (Robin et al., 2016b). Eshghizadeh et al. (2011) showed that salinity affected sigmoid development pattern of Blue panic grass (Panicum antidotale Retz.) roots by reducing the rate of development and size of its components. Borzooei et al. (2015) also reported that the decrease in root surface area in resistant and susceptible wheat varieties is due to the decrease in root size. Although in this study the root surface area was less affected by salinity than the root volume.

\section{Specific root weight}

There was no statistically significant difference between the applying methods of effective microorganisms on specific root weight, although the soil application method of microorganisms effective produced more specific root weight than other application methods. Increased amount of salinity from 0 to $75 \mathrm{mM}$ causes a decrease in the amount of 15.24 percent specific root weight. Lowest specific root weight was observed in $75 \mathrm{mM}$ salinity, which showed no significant difference with $50 \mathrm{mM}$ salinity (Figure 1).The index is less affected by salinity due to its nature, because it is as the result of dividing the dry weight of root to root length. Therefore, the reduction of root length in high salinity levels causes specific root weight increase in higher salinity, which suggests that the roots are more affected by salinity than the root.

\section{Conclusions}

Overall, our result showed that sweet corn was sensitive to salinity stress. Increasing level of salinity was decreased all traits and root was more sensitive than shoot. Use of EM to soil+foliar application was more effective compared to other methods in saline conditions to reduce the effects of salinity although the highest root dry weight, root density and membrane stability were observed in soil application.

\section{References}

Afsharmanesh, G. (2013). Study of the Potential of Sequential Planting of Supersweet and Sweet Corn Hybrids in Greenhouse Conditions of Jiroft Region in Iran. Seed and Plant Production Journal 29, 485-503.

Amiri, J., Eshghi, S., Tafazoli, E., Kholdebarin, B., and Abbaspour, N. (2015). Ameliorative effects of salicylic acid on mineral concentrations in roots and leaves of two grapevine (Vitis vinifera L.) cultivars under salt stress. VITIS-Journal of Grapevine Research 53, 181.

Azarmi, F., Mozaffari, V., Hamidpour, M., and Abbaszadeh-Dahaji, P. (2016). Interactive Effect of Fluorescent Pseudomonads Rhizobacteria and $\mathrm{Zn}$ on the Growth, Chemical Composition, and Water Relations of Pistachio (Pistacia vera L.) Seedlings under $\mathrm{NaCl}$ Stress. Communications in Soil Science and Plant Analysis, 1-18.

Borzouei, A., Jamali, S., and Paknejad, F. (2015). Root characteristics, $\mathrm{Na}^{+} / \mathrm{K}^{+}$ratio and grain yield of seven wheat genotypes under salinity stress. Journal of Science and Technology of Greenhouse Culture 5 , 165-175.

Cirillo, C., Rouphael, Y., Caputo, R., Raimondi, G., Sifola, M., and De Pascale, S. (2016). Effects of high salinity and the exogenous application of an osmolyte on growth, photosynthesis, and mineral composition in two ornamental shrubs. The Journal of Horticultural Science and Biotechnology 91, 14-22.

Eshghizadeh, H.R., Kafi, M., and Nezami, A. (2011). Effect of $\mathrm{NaCl}$ salinity on the pattern and rate of root development of blue panic grass (Panicum antidotaleRetz.). Journal of Science and Technology of Greenhouse Culture 2, 13-28.

Golbashy, M., Ebrahimi, M., Khorasani, S.K., and Choukan, R. (2010). Evaluation of drought tolerance of some corn (Zea mays L.) hybrids in Iran. African Journal of Agricultural Research 5, 2714-2719.

Hampton, M. O., Dittmar, P.T., McAvoy, E.J., Raid, R.N. and Webb, S.E. (2017). Sweet Corn Production. In Dittmar,P.J., Freeman, J,H. and Vallad, G.E. (Editors) Vegetable Production Handbook of Florida 2016-2017. Retrieved from http://edis.ifas.ufl.edu/cv292. 
Higa, T. (2001). Effective Microorganisms in the context of Kyusei Nature Farming: a technology for the future. Paper presented at: Sixth International Conference on Kyusei Nature Farming Pretoria, South Africa.

Hodge, A., and Storer, K. (2015). Arbuscular mycorrhiza and nitrogen: implications for individual plants through to ecosystems. Plant and Soil 386, 1-19.

Hussain, Z., Khattak, R., Fareed, I., Irshad, M., and Mahmood, Q. (2015). Interaction of Phosphorus and Potassium on Corn (Zea mays L.) in Saline-Sodic Soil. Journal of Agricultural Science 7, 66

Jahanban, L., and Lotfifar, O. (2012). Study of the effective organism (EM) application effect on efficacy of chemical and organic fertilizers in corn cultivation (Zea maiz s. C704). Plant Production Technology $11,43-52$.

Javaid, A. (2006). Foliar application of effective microorganisms on pea as an alternative fertilizer. Agronomy for Sustainable Development 26, 257.

Kazemeini, S.A., Hamzehzarghani, H., and Edalat, M. (2010). The impact of nitrogen and organic matter on winter canola seed yield and yield components. Australian Journal of Crop Science 4, 335.

Kazemi, S., Eshghizadeh, H., and Zahedi, M. (2016). Agromorphological responses of Iranian local and improved rice genotypes to salinity of the nutrient solution. Journal of Science and Technology of Greenhouse Culture 7, 153-163.

Lee, K., and Sung, J. (2001). Improvement of Tomato Cultivation by Effective Microorganisms. Paper presented at: Sixth International Conference on Kyusei Nature Farming Proceedings of the conference on greater productivity and a cleaner environment through Kyusei Nature Farming, University of Pretoria, Pretoria, South Africa, 28-31 October, 1999 (International Nature Farming Research Center (INFRC)).

Maas, E.V., and Hoffman, G. (1977). Crop salt tolerance $\backslash$-current assessment. Journal of the Irrigation and Drainage Division 103,115-134.

Majdi, S., Jami, M.M., and Hokmabadi, M. (2013). Root morphological response of two corn inbred lines to salinity stress. Journal of Plant Ecophysiology 5, 34-44.

Merah, O., and Monneveux, P. (2015). Contribution of Different Organs to Grain Filling in Durum Wheat under Mediterranean Conditions I. Contribution of Post-Anthesis Photosynthesis and Remobilization. Journal of Agronomy and Crop Science 201, 344-352.

Nazarly, H., and Seyed, S.R. (2013). Study of qualitative and quantitative yield and some agronomic characteristics of sunflower (Helianthus annus 1.) in response of seed inoculation with pgpr in various levels of nitrogen fertilizer. Journal of Sustainable AgriculturalandProduction Science 23, 27-45.
Pessarakli, M., Huber, J., and Tucker, T. (1989). Dry matter yield, nitrogen absorption, and water uptake by sweet corn under salt stress. Journal of Plant Nutrition 12, 279-290.

Priyadi, K., Hadi, A., Siagian, T.H., Nisa, C., Azizah, A., Raihani, N., and Inubushi, K. (2005). Effect of soil type, applications of chicken manure and effective microorganisms on corn yield and microbial properties of acidic wetland soils in Indonesia. Soil Science \& Plant Nutrition 51, 689-691.

Robin, A.H.K., Matthew, C., Uddin, M.J., and Bayazid, K.N. (2016a). Salinity-induced reduction in root surface area and changes in major root and shoot traits at the phytomer level in wheat. Journal of Experimental Botany 67, 3719-3729.

Robin, A.H.K., Matthew, C., Uddin, M.J., and Bayazid, K.N. (2016b). Salinity-induced reduction in root surface area and changes in major root and shoot traits at the phytomer level in wheat. Journal of Experimental Botany.

Shahrokhi, M., and Khorasani, S.K. (2013). Comparison of Yield and Yield Component on Corn (Zea mays L.) Generations between Saline Condition and Normal Condition. International Journal of Agronomy and Plant Production 4, 399-404.

Shtereva, L., Vassilevska-Ivanova, R., Kraptchev, B., Shtereva, L., Vassilevska-Ivanova, R., and Kraptchev, B. (2015). Evaluation of drought tolerance in new bulgarian sweet corn genotypes with using stress tolerance indices. Genetika-Belgrade 47, 639-650.

Singh, L.P., Gill, S.S., and Tuteja, N. (2011). Unraveling the role of fungal symbionts in plant abiotic stress tolerance. Plant Signaling \&Behavior 6, 175-191

Taffouo, V.D., Kouamou, J.K., Ngalangue, L.M.T., Ndjeudji, B.A.N., and Akoa, A. (2009). Effects of salinity stress on growth, ions partitioning and yield of some cowpea (Vigna unguiculata L. Walp.) cultivars. International Journal of Botany 5, 135-143.

Tracy, W., and Hallauer, A. (1994). Sweet Corn. Specialty Corns, 147187.

Turan, M.A., Elkarim, A.H.A., Taban, N., and Taban, S. (2009). Effect of salt stress on growth, stomatal resistance, proline and chlorophyll concentrations on corn plant. African Journal of Agricultural Research 4, 893-897.

Wang, Q., Dodd, I.C., Belimov, A.A., and Jiang, F. (2016). Rhizosphere bacteria containing 1-aminocyclopropane-1carboxylate deaminase increase growth and photosynthesis of pea plants under salt stress by limiting $\mathrm{Na}+$ accumulation. Functional Plant Biology 43, 161-172.

Yamada, K., and Xu, H.-L. (2001). Properties and applications of an organic fertilizer inoculated with effective microorganisms. Journal of Crop Production 3, 255-268.

\section{Istraživanje metoda primene efektivnih mikroorganizama za ublažavanje efekata sonog stresa na morfologiju korena kukuruza šećerca}

\section{Zahra Sabeti · Mohammad Armin · Mohamad Reza Vaezi Kakhki}

Sažetak: Na morfologiju korena može uticati mnogo faktora poput mikroorganizama. U cilju određivanja uticaja efektivnih mikroorganizama (EM) na morfologiju korena kukuruza šećerca pod sonim stresom, faktorijalni ogled je sproveden kao slučajni kompletni blok dizajna sa tri ponavljanja na Islamskom univerzitetu Azad u Sabzevaru u 2013. Faktori su uključivali primenu EM metoda (primena u zemljište, folijarna primena i primena zemljište+folijarna) $\mathrm{i}$ intenzitet saliniteta $(0,25,50,75 \mathrm{mM})$. Komercijalni rastvor EM je bio primenjen sa 30 litara po hektaru za primenu u zemljište i folijarna primena tokom faze pet listova. Primena u zemljište je pokazala najvišu suvu masu korena, gustinu korena i stabilnost membrane, a zbirna zemljišna i folijarna primena pokazala je najvišu zapreminu korena, dužinu korena i suvu masu korena i izdanka. Sa povećanjem intenziteta saliniteta, vrednosti svih osobina su se smanjile i najviše vrednosti su bile u kontroli. Primena EM u zemljište je otklonila efekte saliniteta bolje od drugih metoda.

Ključne reči: efektivni mikroorganizmi (EM), morfologija korena, kukuruz šećerac, salinitet 